\title{
pH measured 24 hours post mortem should not be regarded as ultimate pH in pork meat quality evaluation
}

\author{
K. Tarczyński ${ }^{1 \#}$, H. Sieczkowska ${ }^{1}$, A. Zybert ${ }^{1}$, E. Krzęcio-Nieczyporuk ${ }^{2}$ \& K. Antosik ${ }^{2}$ \\ ${ }^{1}$ Department of Pig Breeding and Meat Science, ${ }^{2}$ Department of Health Science; \\ Siedlce University of Natural Sciences and Humanities, 08-110 Siedlce, Prusa 14 Street, Poland
}

(Received 15 February 2018; Accepted 1 August 2018; First published online 29 November 2018)

\author{
Copyright resides with the authors in terms of the Creative Commons Attribution 4.0 South African License See: \\ http://creativecommons.org/licenses/by/4.0/za \\ Condition of use: The user may copy, distribute, transmit and adapt the work, but must recognize the authors and the South African \\ Journal of Animal Science
}

\begin{abstract}
The aim of this study was to compare the diagnostic values of two methods in pork meat quality evaluation, that is, Method I: $\mathrm{pH}_{1}$ and $\mathrm{pH}_{24}$ and Method II: electrical conductivity $\left(\mathrm{EC}_{2}\right)$ and $\mathrm{pH}_{24}$, which included $\mathrm{pH}_{24}$, and their modifications, that is, Method III: $\mathrm{pH}_{1}$ and $\mathrm{pH}_{48}$ and Method IV: $\mathrm{EC}_{2}$ and $\mathrm{pH}_{48}$, which included $\mathrm{pH}_{48}$ measurement. Five meat quality classes, namely reddish-pink, firm and non-exudative (RFN), high quality (HQ), pale, soft and exudative (PSE), dark, firm and dry (DFD) and acid meat (AM) were assessed in four even-numbered genetic groups of 40 fatteners each, namely $(L \times Y) \times D-A,(L \times Y) \times D-B$, $(\mathrm{L} \times \mathrm{Y}) \times \mathrm{H}$ and $(\mathrm{L} \times \mathrm{Y}) \times(\mathrm{D} \times \mathrm{P})$. The change of diagnostic method and therefore $\mathrm{pH}$ time measurement from 24 hours to 48 hours post mortem caused a major increase in the percentage of acid meat (AM) that was diagnosed. Most differences were observed in $(\mathrm{L} \times \mathrm{Y}) \times \mathrm{H}$ fatteners, namely $77.5 \%$ between Methods I and III and $75 \%$ between Methods II and IV. This increase in AM frequency indicates that as a result of significant changes in the post-mortem metabolism that occur in the meat ageing process $\mathrm{pH}_{48}$ should be regarded as ultimate $\mathrm{pH}\left(\mathrm{pH}_{\mathrm{u}}\right)$.
\end{abstract}

\section{Keywords: Acid meat, fatteners, post-mortem muscle metabolism}

\#Corresponding author: krystian.tarczynski@uph.edu.pl

\section{Introduction}

Since the second half of the twentieth century, meat consumption has been increasing worldwide (Valsta et al., 2005) and a further annual increase of 1.4\% is expected until 2024 (OECD-FAO, 2015). In Europe, the rise in meat consumption is related mainly to so-called fresh, that is, unprocessed meat (Breidenstein \& Williams, 1987; Deutscher Fleisch-Verband, 2003; Alcalde et al., 2013). However, a major increase in lean meat content and fattening traits of pigs in the past 60 years has caused a deterioration in pork meat quality (Przybylski et al., 2012). Moreover, modern consumers attach excessive importance to the quality of purchased products, regardless of the strict monitoring of product quality that is implemented by pork processors nowadays (Verbeke et al., 2007). Additionally, meat processors and consumers suffer major financial losses owing to meat quality defects such as bright colour and increased drip loss (Fischer, 2007; Otto et al., 2007).

Additionally, modern pig breeding has resulted in major changes in the meat ageing process such as the time at which ultimate $\mathrm{pH}\left(\mathrm{pH}_{\mathrm{u}}\right)$ is fully achieved (see, inter alia, Zybert et al., 2008). This seems to be an important topic because of the effect of the post-mortem $\mathrm{pH}$ decline and extent in meat on its overall quality, among others water holding capacity (WHC) (Schäfer et al., 2002), drip loss (Fischer, 2007), protein structure (Huff-Lonergan \& Lonergan, 2005) and shelf-life (Blixt \& Borch, 2002). Although diagnostic methods of assessing pork meat quality use parameters that are measured up to 24 hours post mortem (such as $\mathrm{pH}$ value) and differentiate between reddish-pink, firm and non-exudative (RFN) meat and faulty meat such as pale, soft and exudative (PSE) and dark, firm and dry (DFD) meat (Koćwin-Podsiadła et al., 2006), because of recent changes in pig genotypes an assessment of acid meat (AM) is required.

The evaluation of pork meat quality classes based on methods that include $\mathrm{pH}_{24}$ measurement is generally well studied, but there is still insufficient data based on the methods such as $\mathrm{pH}_{48}$ measurements and their usefulness in modern pig production. Therefore, the aim of this study was to compare the diagnostic value of two methods of pork quality evaluation, that is, Method I: $\mathrm{pH}_{1}$ and $\mathrm{pH}_{24}$ and Method II: 
$\mathrm{EC}_{2}$ and $\mathrm{pH}_{24}$, which included $\mathrm{pH}_{24}$, and their modifications, that is, Method III: $\mathrm{pH}_{1}$ and $\mathrm{pH}_{48}$ and Method IV: $\mathrm{EC}_{2}$ and $\mathrm{pH}_{48}$, which included $\mathrm{pH}_{48}$ measurement.

\section{Materials and Methods}

The research was carried out on 160 pigs during the fattening phase. Four genetic groups of fatteners (40 pigs per group with equal amounts of male and female) were examined, namely (Landrace $\times$ Yorkshire) $\times$ Duroc-A $((L \times Y) \times D-A)$, (Landrace $\times$ Yorkshire $) \times$ Duroc $-B((L \times Y) \times D-B)$, (Landrace $\times$ Yorkshire $) \times$ Hampshire $((L \times Y) \times H)$, and (Landrace $\times$ Yorkshire $) \times($ Duroc $\times$ Piétrain) $((L \times Y) \times(D \times P))$. The genetic groups $(L \times Y) \times D-A$ and $(L \times Y) \times D-B$ were differentiated by the origin of the paternal component from Poland $(A)$ and from Denmark (B). Maintenance and nutrition conditions were the same for all animals throughout the rearing. Complete feeds were given according to age. The fatteners were slaughtered at approximately 100 $\mathrm{kg}$ live weight in autumn (in September and November) within four hours of transportation (approximately $280 \mathrm{~km}$ ). Stunning was performed with an electric stunner (MIDAS, Stork RMS, The Netherlands) and INARCO constant voltage system. Animals were bled lying down in accordance with the technology applied at one of the leading meat plants in Mazowsze district in Poland. Lean meat content was determined 35 min. post mortem by ULTRA-FOM 300 (SFK-Technology), and hot carcass weight (HCW) was measured immediately afterwards (accuracy up to $0.1 \mathrm{~kg}$ ). Then meat was chilled in a three-phase chilling tunnel $(-10$ ${ }^{\circ} \mathrm{C}$ for $15 \mathrm{~min}$., then $-15^{\circ} \mathrm{C}$ for $25 \mathrm{~min}$., and $-5{ }^{\circ} \mathrm{C}$ for $40 \mathrm{~min}$.) with air velocity of $3 \mathrm{~m} / \mathrm{s}$, and stored at $4{ }^{\circ} \mathrm{C}$ up to 24 hours post mortem.

The genomic DNA was isolated from white blood cells, according to Kawasaki (1990). The $R Y R^{1} \mathrm{C} 1843 \mathrm{~T}$ polymorphic site was analysed with DNA test using the PCR/RFLP method, according to Fujii et al. (1991).

The quality of samples of fresh meat (35 min. immediately after bleeding) and cooled meat (after 24 hours of chilling) was evaluated after slaughter on the longissimus lumborum (LL) muscle (after last rib). Acidity of the muscle tissue $(\mathrm{pH})$ was measured directly in carcasses $35 \mathrm{~min}$. $\left(\mathrm{pH}_{1}\right)$, and in meat samples in 24 hours $\left(\mathrm{pH}_{24}\right)$ and 48 hours $\left(\mathrm{pH}_{48}\right)$ using a calibrated pistol pH-meter MASTER (Draminski, Olsztyn, Poland) with temperature compensation. Electrical conductivity (EC) was measured with a LF-Star electrical conductivity meter (Ingenieurburo Matthaus, Noblitz, Germany) after 2 hours $\left(E_{2}\right)$ and 24 hours $\left(E_{24}\right)$. Colour lightness of muscle tissue was measured after 24 hours $\left(\mathrm{L}_{24}^{*}\right)$ with a Minolta chroma meter (model CR 310, Minolta, Osaka, Japan) using D65 illuminant and $50 \mathrm{~mm}$ orifice. WHC was determined after 24 hours by the filter paper press method (Whatman 4 filter paper) according to Grau \& Hamm method (1952) modified by Pohja \& Ninivaara (1957). DL was determined according to Prange et al. (1977) after 48 hours $\left(\mathrm{DL}_{48}\right), 96$ hours $\left(\mathrm{DL}_{96}\right)$, and 144 hours $\left(\mathrm{DL}_{144}\right)$ at a storage temperature at $4{ }^{\circ} \mathrm{C}$. Meat yield after the curing and thermal processing $\left(72^{\circ} \mathrm{C}\right)$ was expressed by the TY (technological yield) indicator according to Naveau et al. (1985).

The water, dry matter, total protein and intramuscular fat contents (IMF) of the $L L$ muscle were determined in accordance with procedures recommended by the AOAC, namely water and dry matter: method: 950.46; protein: method 968.06; IMF: method 991.36 (AOAC, 2000).

Meat samples were cut from the $L L$ muscle 35 min. post mortem, immersed immediately in tubes with $1 \mathrm{M} \mathrm{HClO}_{4}$, homogenized to inhibit glycolytic changes, and analysed for the value of glycolytic potential (GP) and its components, for example glycogen and lactate. The content of glycogen was determined by the enzymatic method, according to Dalrymple \& Hamm (1973) and lactate according to Bergmeyer (1974). The GP was calculated as the sum of 2 [glycogen] + [lactate] according to Monin \& Sellier (1985) and expressed as $\mu \mathrm{mol}$ of lactic acid equivalent per $\mathrm{g}$ of fresh muscle. Rate of adenosine triphosphate (ATP) breakdown, expressed as $\mathrm{R}_{1}$ (IMP/ATP ratio), was determined $35 \mathrm{~min}$. after slaughter on meat samples taken after the last rib, according to Honikel \& Fischer (1977).

In the current study meat quality classes, for example RFN, high quality (HQ), PSE, AM and DFD, were evaluated based on diagnostic methods and their parameter threshold values accepted by KoćwinPodsiadła et al. (2006) (Table 1). Additionally, the frequency of AM was evaluated based on two methods using $\mathrm{pH}_{48}$ parameter, for example $\mathrm{pH}_{1}(\geq 6.0)$ and $\mathrm{pH}_{48}(\leq 5.4)$ (Method III) and $\mathrm{EC}_{2}(\leq 4.5)$ and $\mathrm{pH}_{48}(\leq 5.4)$ (Method IV).

Moreover, variability of $\mathrm{pH}$ was measured 48 hours post mortem and expressed as its minimal and maximal values and their arithmetical differences.

Data were analysed by one-way analysis of variance using an orthogonal contrast in Statistica 12.5 (StatSoft, Tulsa, OK, USA). The model was expressed as follows:

$$
y_{i}=\mu+a_{i}+e_{i}
$$

where: $y_{i}-$ measured $i^{\text {th }}$ trait 


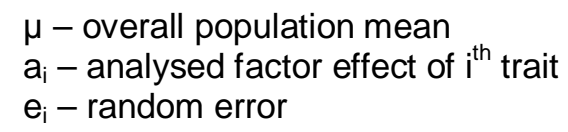

The significance of differences between means was calculated using NIR test.

Table 1 Threshold values of parameters used for basic meat quality class evaluation

\begin{tabular}{|c|c|c|c|c|}
\hline \multirow{3}{*}{$\begin{array}{l}\text { Meat quality } \\
\text { classes }\end{array}$} & \multicolumn{4}{|c|}{ Diagnostic methods } \\
\hline & \multicolumn{2}{|c|}{$\mathrm{I}-\mathrm{pH}_{1}$ and $\mathrm{pH}_{24}$} & \multicolumn{2}{|c|}{$\mathrm{II}-\mathrm{EC}_{2}$ and $\mathrm{pH}_{24}$} \\
\hline & $\mathrm{pH}_{1}$ & $\mathrm{pH}_{24}$ & $\mathrm{EC}_{2}$ & $\mathrm{pH}_{24}$ \\
\hline RFN & $\geq 6.0$ & $5.5-6.0$ & $\leq 4.5$ & $5.5-6.0$ \\
\hline HQ & - & - & $\leq 4.5$ & $5.5-5.7$ \\
\hline PSE & $<6.0$ & $<5.5$ & $>7.5$ & $<5.5$ \\
\hline DFD & $\geq 6.0$ & $\geq 6.0$ & $\leq 4.5$ & $>6.0$ \\
\hline AM & $\geq 6.0$ & $<5.5$ & $\leq 4.5$ & $<5.5$ \\
\hline
\end{tabular}

RFN - reddish-pink, firm and non-exudative; HQ - high quality; PSE - pale, soft and exudative; DFD - dark, firm and dry; $\mathrm{AM}$ - acid meat; $\mathrm{pH}_{1}-\mathrm{pH}$ measured 45 min. post mortem; $\mathrm{pH}_{24}-\mathrm{pH}$ measured 24 hours post mortem;

$\mathrm{EC}_{2}$ - electrical conductivity measured 2 hours post mortem

Parameters threshold values accordingly to Koćwin-Podsiadła et al. (2006)

\section{Results and Discussion}

In the current study, the average HCW and lean meat content were equal to $85.44 \pm 3.30 \mathrm{~kg}$ and $56.51 \pm 3.61 \%$, respectively.

Among the fatteners no $R Y R 1^{\top} R Y R 1^{\top}$ genotypes were diagnosed. $R Y R 1^{\mathrm{C}} R Y R 1^{\top}$ genotypes were diagnosed only in the $(L \times Y) \times(D \times P)$ group in $30 \%$ of animals. The remaining groups were $R Y R 1^{\top}$ allele free.

The chemical composition, glycolytic-energetic determinants, meat quality and technological value traits are shown in Table 2. The most favourable values of glycolytic-energetic determinants, namely glycolytic potential $(130.72 \pm 21.57$ and $135.38 \pm 20.58 \mu \mathrm{mol} / \mathrm{g})$, and its components glycogen $(45.40 \pm 11.05$ and $46.68 \pm 11.04 \mu \mathrm{mol} / \mathrm{g})$, lactic acid $(39.91 \pm 9.27$ and $42.03 \pm 8.33 \mu \mathrm{mol} / \mathrm{g}), \mathrm{pH}_{1}(6.62 \pm 0.17$ and $6.60 \pm$ $0.14), \mathrm{pH}_{24}(5.71 \pm 0.12$ and $5.74 \pm 0.09)$, and IMF content $(2.06 \pm 0.71 \%$ and $2.13 \pm 0.73 \%)$ were obtained in $(L \times Y) \times D-A$ and $(L \times Y) \times D-B$ groups, respectively (Table 2$)$.

Table 2 Influence of genetic group on chemical composition of meat

\begin{tabular}{|c|c|c|c|c|c|c|}
\hline \multirow[b]{2}{*}{ Trait } & \multicolumn{6}{|c|}{ Genetic group } \\
\hline & $\begin{array}{c}(L \times Y) \times D-A \\
n=40\end{array}$ & $\begin{array}{c}(L \times Y) \times D-B \\
n=40\end{array}$ & $\begin{array}{c}(L \times Y) \times H \\
n=40\end{array}$ & $\begin{array}{c}(L \times Y) \times(D \times P) \\
n=40\end{array}$ & $\begin{array}{c}\text { Total } \\
\mathrm{N}=160\end{array}$ & $\begin{array}{c}\text { Femp. and }_{\text {statistical }} \\
\text { significance }\end{array}$ \\
\hline Water content [\%] & $74.85^{\mathrm{BC}} \pm 0.82$ & $72.79^{A} \pm 0.90$ & $74.60^{B} \pm 0.72$ & $75.26^{c} \pm 0.28$ & $74.38 \pm 1.19$ & $92.00^{* *}$ \\
\hline Dry matter content [\%] & $25.15^{B} \pm 0.82$ & $27.22^{c} \pm 0.89$ & $25.40^{B} \pm 0.72$ & $23.31^{A} \pm 0.98$ & $25.27 \pm 1.63$ & $138.8^{* *}$ \\
\hline IMF content [\%] & $2.06^{\mathrm{B}} \pm 0.71$ & $2.13^{B} \pm 0.73$ & $1.27^{\mathrm{A}} \pm 0.40$ & $1.42^{A} \pm 0.20$ & $1.72 \pm 0.67$ & $24.68^{* *}$ \\
\hline Protein content [\%] & $22.32^{A} \pm 0.56$ & $23.54^{B} \pm 0.69$ & $22.54^{\mathrm{A}} \pm 0.93$ & $22.64^{\mathrm{A}} \pm 0.45$ & $22.76 \pm 0.81$ & $25.20^{* *}$ \\
\hline
\end{tabular}

A,B,C Row means with different superscripts differ significantly at $P<0.01$

$(L \times Y) \times D-A-($ Landrace $\times$ Yorkshire $) \times$ Duroc-A (paternal component from Poland); $(L \times Y) \times D-B$ (Landrace $\times$ Yorkshire $) \times$ Duroc-A (paternal component from Denmark); $(L \times Y) \times H-($ Landrace $\times$ Yorkshire) $\times$ Hampshire; $(L \times Y) \times(D \times P)-$ (Landrace $\times$ Yorkshire $) \times($ Duroc $\times$ Piétrain $)$

IMF: intramuscular fat 
Analogous drift was observed for $\mathrm{R}_{1}(0.86 \pm 0.05$ and $0.90 \pm 0.01)$ and $\mathrm{EC}_{2}(2.62 \pm 0.58$ and $1.92 \pm$ $0.46 \mathrm{mS} / \mathrm{cm}$ ) parameters (Table 3). The lowest drip loss (DL), measured in $48(4.05 \pm 1.67 \%), 96(7.31 \pm$ $2.01 \%)$, and $144(9.38 \pm 2,42 \%)$ hours post mortem, was obtained in $(L \times Y) \times D-B$ fatteners. The least favourable values of glycolytic-energetic determinants, namely glycolytic potential $(177.39 \pm 52.05 \mu \mathrm{mol} / \mathrm{g})$, glycogen $(63.92 \pm 25.91 \mu \mathrm{mol} / \mathrm{g}), \mathrm{pH}_{48}(5.35 \pm 0.09), \mathrm{DL}_{144}(12.63 \pm 3.29), \mathrm{WHC}\left(7.19 \pm 1.21 \mathrm{~cm}^{2}\right)$ and technological yield (TY) $(89.57 \pm 5.82 \%)$ were assessed in $(\mathrm{L} \times \mathrm{Y}) \times \mathrm{H}$ group (Table 3$)$. The values obtained for $\mathrm{pH}_{1}, \mathrm{pH}_{24}$ and $\mathrm{EC}_{2}$ parameters were typical of RFN meat, according to Koćwin-Podsiadła et al. (2006) (Table 1).

Table 3 Influence of genetic group on glycolytic-energetic parameters and meat quality traits

\begin{tabular}{|c|c|c|c|c|c|c|}
\hline \multirow[b]{2}{*}{ Trait } & \multicolumn{6}{|c|}{ Genetic group } \\
\hline & $\begin{array}{c}(L \times Y) \times D-A \\
n=40\end{array}$ & $\begin{array}{c}(L \times Y) \times D-B \\
n=40\end{array}$ & $\begin{array}{c}(L \times Y) \times H \\
n=40\end{array}$ & $\begin{array}{c}(L \times Y) \times(D \times P) \\
n=40\end{array}$ & $\begin{array}{c}\text { Total } \\
N=160\end{array}$ & $\begin{array}{c}\mathbf{F}_{\text {emp. }} \text { and } \\
\text { statistical } \\
\text { significance }\end{array}$ \\
\hline $\begin{array}{l}\text { Glycolytic potential } \\
{[\mu \mathrm{mol} / \mathrm{g}]}\end{array}$ & $\begin{array}{c}130.72^{A} \pm \\
21.57\end{array}$ & $\begin{array}{c}135.38^{A} \pm \\
20.58\end{array}$ & $\begin{array}{l}177.39^{\mathrm{B}} \pm \\
52.05\end{array}$ & $\begin{array}{c}134.75^{A} \pm \\
24.46\end{array}$ & $\begin{array}{c}144.56 \pm \\
37.34\end{array}$ & $18.42^{* *}$ \\
\hline Glycogen $[\mu \mathrm{mol} / \mathrm{g}]$ & $45.40^{A} \pm 11.05$ & $46.68^{A} \pm 11.04$ & $63.92^{B} \pm 25.91$ & $42.79^{A} \pm 13.08$ & $49.70 \pm 18.34$ & $13.62^{* *}$ \\
\hline Lactate $[\mu \mathrm{mol} / \mathrm{g}]$ & $39.91^{A} \pm 9.27$ & $42.03^{A} \pm 8.33$ & $49.55^{B} \pm 12.29$ & $49.90^{B} \pm 11.96$ & $45.35 \pm 11.40$ & $9.37^{* *}$ \\
\hline $\mathrm{R}_{1}$ & $0.86^{A} \pm 0.05$ & $0.90^{B} \pm 0.01$ & $0.96^{c} \pm 0.05$ & $0.94^{c} \pm 0.06$ & $0.92 \pm 0.06$ & $38.94^{* *}$ \\
\hline $\mathrm{pH}_{1}$ & $6.62^{B} \pm 0.17$ & $6.60^{B} \pm 0.14$ & $6.44^{A} \pm 0.21$ & $6.49^{A} \pm 0.18$ & $6.54 \pm 0.19$ & $9.50^{* *}$ \\
\hline $\mathrm{pH}_{24}$ & $5.71^{B} \pm 0.12$ & $5.74^{B} \pm 0.09$ & $5.61^{A} \pm 0.10$ & $5.66^{A} \pm 0.11$ & $5.68 \pm 0.12$ & $10.50^{* *}$ \\
\hline $\mathrm{pH}_{48}$ & $5.51^{B} \pm 0.12$ & $5.52^{B} \pm 0.08$ & $5.35^{A} \pm 0.09$ & $5.55^{\mathrm{B}} \pm 0.12$ & $5.48 \pm 0.13$ & $27.20^{* *}$ \\
\hline $\mathrm{EC}_{2}[\mathrm{mS} / \mathrm{cm}]$ & $2.62^{B} \pm 0.58$ & $1.92^{A} \pm 0.46$ & $3.18^{c} \pm 0.86$ & $3.02^{c} \pm 0.84$ & $2.69 \pm 0.85$ & $25.26^{*}$ \\
\hline $\mathrm{EC}_{24}[\mathrm{mS} / \mathrm{cm}]$ & $4.48^{B} \pm 1.15$ & $2.59^{A} \pm 0.57$ & $4.87^{B} \pm 1.57$ & $5.12^{\mathrm{B}} \pm 1.70$ & $4.27 \pm 1.65$ & $29.87^{* *}$ \\
\hline$L_{24}^{*}$ & $53.90^{a} \pm 2.77$ & $54.84^{\mathrm{ab}} \pm 2.84$ & $55.55^{b} \pm 2.58$ & $53.99^{\mathrm{a}} \pm 2.55$ & $54.57 \pm 2.75$ & $3.34^{*}$ \\
\hline $\mathrm{DL}_{48}[\%]$ & $5.67^{B} \pm 2.43$ & $4.05^{A} \pm 1.67$ & $5.77^{B} \pm 2.79$ & $7.54^{c} \pm 3.44$ & $5.76 \pm 2.91$ & $11.48^{* *}$ \\
\hline $\mathrm{DL}_{96}[\%]$ & $8.73^{B} \pm 2.80$ & $7.31^{A} \pm 2.01$ & $10.03^{c} \pm 3.41$ & $10.02^{c} \pm 3.48$ & $9.02 \pm 3.16$ & $7.54^{* *}$ \\
\hline $\mathrm{DL}_{144}[\%]$ & $11.49^{B} \pm 3.02$ & $9.38^{A} \pm 2.42$ & $12.63^{c} \pm 3.29$ & $12.10^{\mathrm{BC}} \pm 3.53$ & $11.40 \pm 3.31$ & $8.49^{* *}$ \\
\hline $\mathrm{WHC}\left[\mathrm{cm}^{2}\right]$ & $5.46^{A} \pm 1.13$ & $4.88^{A} \pm 1.30$ & $7.19^{B} \pm 1.21$ & $5.44^{\mathrm{A}} \pm 1.15$ & $5.74 \pm 1.47$ & $27.96^{* *}$ \\
\hline TY [\%] & $105.27^{C} \pm 4.04$ & $92.60^{B} \pm 3.37$ & $89.57^{A} \pm 5.82$ & $105.41^{c} \pm 3.79$ & $98.21 \pm 8.42$ & $145.92^{\star \star}$ \\
\hline
\end{tabular}

${ }^{\mathrm{A}, \mathrm{B}, \mathrm{C}}$ Row means with different superscripts differ significantly at $P<0.01$

${ }^{a, b, c}$ Row means with different superscripts differ significantly at $P<0.05$

$(L \times Y) \times D-A-($ Landrace $\times$ Yorkshire $) \times$ Duroc-A (paternal component from Poland); $(L \times Y) \times D-B$ (Landrace $\times$ Yorkshire $) \times$ Duroc-A (paternal component from Denmark); $(L \times Y) \times H-($ Landrace $\times$ Yorkshire) $\times$ Hampshire; $(L \times Y) \times(D \times P)-$ (Landrace $\times$ Yorkshire $) \times($ Duroc $\times$ Piétrain)

$\mathrm{R}_{1}$ - IMP/ATP ratio measured 35 min. post mortem; $\mathrm{pH}_{1}, \mathrm{pH}_{24}$ and $\mathrm{pH}_{48}-\mathrm{pH}$ measured 45 min., 24 hours and 48 hours post mortem; $\mathrm{EC}_{2}$ and $\mathrm{EC}_{24}$ - electrical conductivity measured 2 hours and 24 hours post mortem; $\mathrm{L}^{*}{ }_{24}-\mathrm{colour}_{\text {lightness }}$ of muscle tissue measured 24 hours post mortem; $\mathrm{DL}_{48}, \mathrm{DL}_{96}$ and $\mathrm{DL}_{144}$ - drip loss measured after 48 hours, 96 hours and 144 hours post mortem; WHC - water holding capacity; TY - technological yield

In the current study based on Method I, three meat quality classes were assessed, namely RFN, PSE, and AM, as $96.87 \%, 1.88 \%$ and $1.25 \%$, respectively (Figure 1). PSE meat was obtained in (L×Y) $\times$ D-A, $(L \times Y) \times D-B$, and $(L \times Y) \times(D \times P)$ fatteners, at $2.5 \%$ each (Figure 1$)$. Acid meat was obtained only in $(L \times Y) \times H$ group at $5 \%$ (Figure 1). Based on Method II, four meat quality classes were diagnosed, namely RFN (37.5\%), HQ (59.38\%), PSE (1.87\%), and AM (1.25\%) (Figure 2). The percentages of AM and PSE in the current study and genetic groups were identical to those based on Method I. Based on Method I (and with the same threshold values that were used in this article) a similar frequency of RFN meat was noticed by Sieczkowska et al. (2009) in $(L \times Y) \times D$ and $(L \times Y) \times H$ fatteners at $100 \%$ and $95 \%$, respectively. Przybylski et al. (2012) diagnosed almost $85 \%$ of RFN meat based on $\mathrm{pH}_{1}(\geq 6,0), \mathrm{pH}_{3}(\geq 6,0)$ and $\mathrm{pH}_{24}(\geq 5,5)$ parameters in Naïma × P76 crossbreed. 


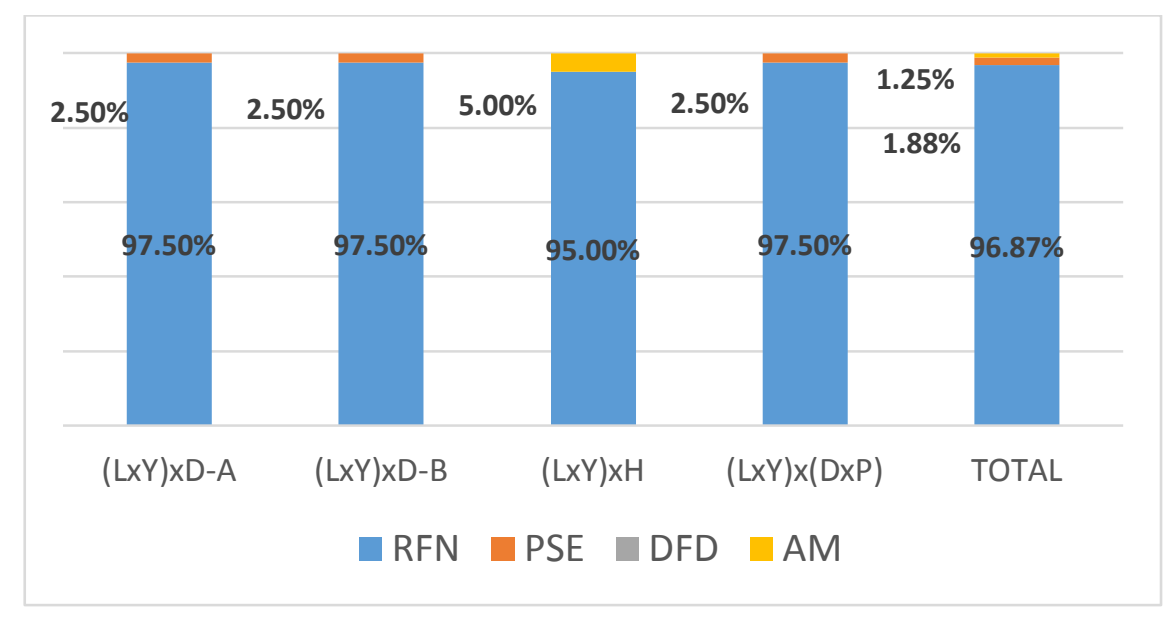

Figure 1 Frequencies (\%) of meat quality classes based on $\mathrm{pH}_{1}$ and $\mathrm{pH}_{24}$ parameters and genetic groups $(L \times Y) \times D-A-($ Landrace $\times$ Yorkshire) $\times$ Duroc-A (paternal component from Poland); (L×Y) $\times D-B($ Landrace $\times$ Yorkshire $) \times$ Duroc-A (paternal component from Denmark); $(\mathrm{L} \times \mathrm{Y}) \times \mathrm{H}-($ Landrace $\times$ Yorkshire) $\times$ Hampshire; $(\mathrm{L} \times \mathrm{Y}) \times(\mathrm{D} \times \mathrm{P})-$ (Landrace $\times$ Yorkshire $) \times($ Duroc $\times$ Piétrain)

RFN - reddish-pink, firm and non-exudative; PSE - pale, soft and exudative; DFD - dark, firm and dry; AM - acid meat

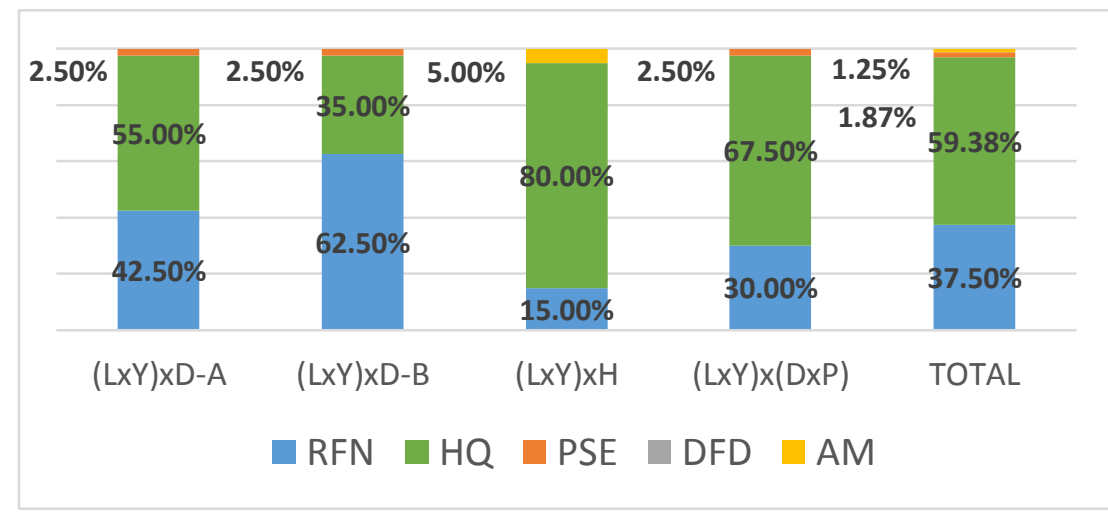

Figure 2 Frequencies (\%) of meat quality classes based on $\mathrm{EC}_{2}$ and $\mathrm{pH}_{24}$ parameters and genetic groups $(L \times Y) \times D-A-($ Landrace $\times$ Yorkshire) $\times$ Duroc-A (paternal component from Poland); $(L \times Y) \times D-B($ Landrace $\times$ Yorkshire $) \times$ Duroc-A (paternal component from Denmark); $(\mathrm{L} \times \mathrm{Y}) \times \mathrm{H}-($ Landrace $\times$ Yorkshire) $\times$ Hampshire; $(\mathrm{L} \times \mathrm{Y}) \times(\mathrm{D} \times \mathrm{P})-$ (Landrace $\times$ Yorkshire $) \times($ Duroc $\times$ Piétrain)

RFN - reddish-pink, firm and non-exudative; HQ - high quality; PSE - pale, soft and exudative; DFD - dark, firm and dry; AM - acid meat

However, the low frequencies of AM obtained in this survey based on Method I and Method II parameters (Figure 1 and 2) do not correspond with high glycolytic potential $(177.39 \pm 52.05 \mu \mathrm{mol} / \mathrm{g})$ and its components, for example glycogen $(63.92 \pm 25.91 \mu \mathrm{mol} / \mathrm{g})$ and lactic acid $(49.55 \pm 12.29 \mu \mathrm{mol} / \mathrm{g})$, which were assessed in $(\mathrm{L} \times \mathrm{Y}) \times \mathrm{H}$ group (Table 2). The Hampshire breed is related with AM, which is associated with $\mathrm{RN}^{-}$phenotype that causes low $\mathrm{pH}_{\mathrm{u}}$ value because of its high glycogen content during slaughter (Monin \& Sellier, 1985). The low level of $\mathrm{AM}$ that was assessed based on diagnostic methods, including $\mathrm{pH}_{24}$ parameters, confirms that the time at which $\mathrm{pH}_{\mathrm{u}}$ is fully achieved has been extended, as reported by Zybert et al. (2008). According to the low level of $A M$ in $(L \times Y) \times H$ group evaluated based on Method I and Method II (Figures 1 and 2) the need to modify them by changing $\mathrm{pH}_{24}$ parameter to $\mathrm{pH}_{48}$ parameter in Method III and Method IV became apparent. An additional motivation to evaluate meat quality based on $\mathrm{pH}_{48}$ hours was the wide variability obtained in the current study $(5.24-5.90)$ and in the genetic groups, for example $(L \times Y) \times D-A$ (5.30-5.90), $(L \times Y) \times D-B(5.37-5.75),(L \times Y) \times H(5.24-5.63)$, and $(L \times Y) \times(D \times P)-(5.30-5.88)(T a b l e ~ 4)$. 
Table 4 Variability of $\mathrm{pH}$ value measured 48 hours post mortem in genetic groups

\begin{tabular}{llll}
\hline \multirow{2}{*}{ Genetic group } & \multicolumn{2}{c}{ pH $_{\mathbf{4 8}}$} \\
\cline { 2 - 4 } & min. & max. & max.-min. \\
\hline$(L \times Y) \times D-A$ & 5.30 & 5.90 & 0.60 \\
$(L \times Y) \times D-B$ & 5.37 & 5.75 & 0.37 \\
$(L \times Y) \times H$ & 5.24 & 5.63 & 0.39 \\
$(L \times Y) \times(D \times P)$ & 5.30 & 5.88 & 0.58 \\
Total & 5.24 & 5.90 & 0.66 \\
\hline
\end{tabular}

min.: minimum value observed

max.: maximum value observed

$(L \times Y) \times D-A-($ Landrace $\times$ Yorkshire $) \times$ Duroc-A (paternal component from Poland); $(L \times Y) \times D-B$ (Landrace $\times$ Yorkshire $) \times$ Duroc-A (paternal component from Denmark); $(\mathrm{L} \times \mathrm{Y}) \times \mathrm{H}-($ Landrace $\times$ Yorkshire $) \times$ Hampshire; $(\mathrm{L} \times \mathrm{Y}) \times(\mathrm{D} \times \mathrm{P})-$ (Landrace $\times$ Yorkshire $) \times($ Duroc $\times$ Piétrain $)$

The use of the $\mathrm{pH}_{48}$ parameter caused major increases in AM frequency in $(\mathrm{L} \times \mathrm{Y}) \times \mathrm{H}$ fatteners. Based on Method III and Method IV, $82.5 \%$ and $80 \%$ of $A M$ in $(L \times Y) \times H$ group were obtained, respectively (Figure 3 and 4). Therefore, differences of AM level diagnosed between Method I and Method III and Method II and Method IV equals $77.5 \%$ and $75 \%$, respectively. This high increase in AM level was probably caused by significant changes in post mortem metabolism that occurred in the meat ageing process as a consequence of modern pig breeding. The confirmation of these results is the high frequency (90\%) of AM in (L×Y) $\times \mathrm{H}$ fatteners based on $\mathrm{pH}_{1}, \mathrm{pH}_{48}$ and $\mathrm{R}_{1}$ parameters (Sieczkowska et al., 2010). Moreover, AM was diagnosed in $(L \times Y) \times D-A,(L \times Y) \times D-B$, and $(L \times Y) \times(D \times P)$ groups (Figure 3 and 4$)$. The Duroc breed, which is regarded as contributing towards improved meat quality, is also seen as being $\mathrm{RN}^{-}$free (Houde et al., 2002). In this survey, however, $10 \%, 7.5 \%$ and $10 \%$ of $A M$ were diagnosed based on Method III in (LXY) $\times D-A,(L \times Y) \times D-B$ and $(L \times Y) \times(D \times P)$, respectively (Figure 3 ). Slightly lower values of $A M$ were obtained based on Method IV in these genetic groups, for example 10\%, 2.5\% and 7.5\%, respectively (Figure 4). Altogether, in the current study, based on Method III and Method IV, 27.5\% and 25\% AM was obtained appropriately (Figures 3 and 4). Although the use of the $\mathrm{pH}_{48}$ parameter increased the frequency of $\mathrm{AM}$ in the fatteners, its usefulness for proper meat classification is low owing to the late time of measurement.

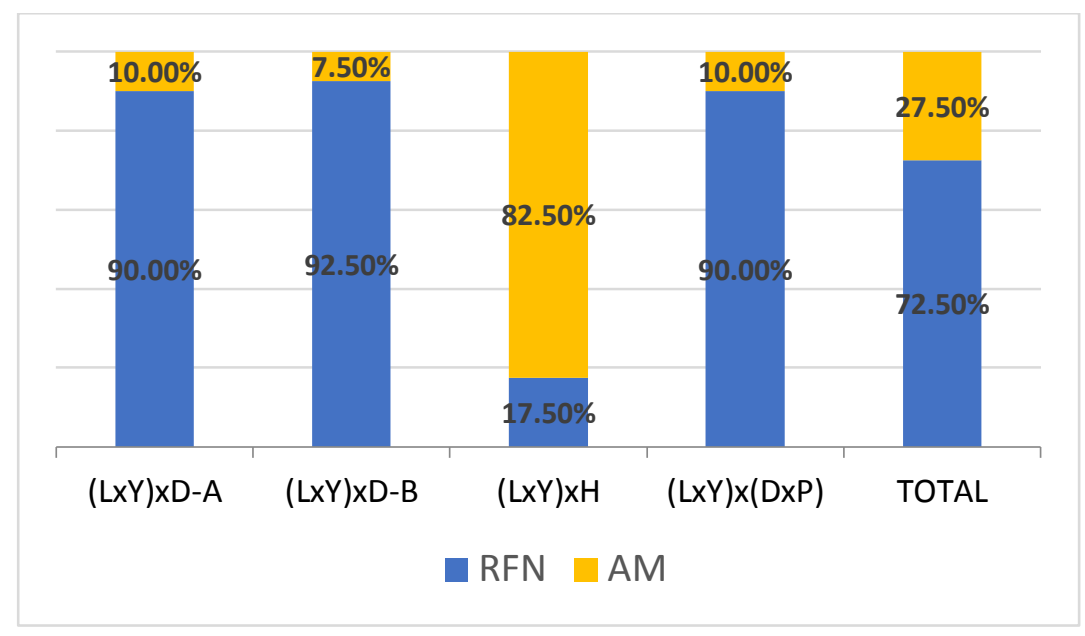

Figure 3 Frequencies (\%) of meat quality classes based on $\mathrm{pH}_{1}$ and $\mathrm{pH}_{48}$ parameters and genetic groups $(L \times Y) \times D-A-($ Landrace $\times$ Yorkshire $) \times$ Duroc-A (paternal component from Poland); $(L \times Y) \times D-B($ Landrace $\times$ Yorkshire $) \times$ Duroc-A (paternal component from Denmark); $(\mathrm{L} \times \mathrm{Y}) \times \mathrm{H}-($ Landrace $\times$ Yorkshire) $\times$ Hampshire; $(\mathrm{L} \times \mathrm{Y}) \times(\mathrm{D} \times \mathrm{P})-$ (Landrace $\times$ Yorkshire $) \times($ Duroc $\times$ Piétrain $)$

RFN - reddish-pink, firm and non-exudative; AM - acid meat 


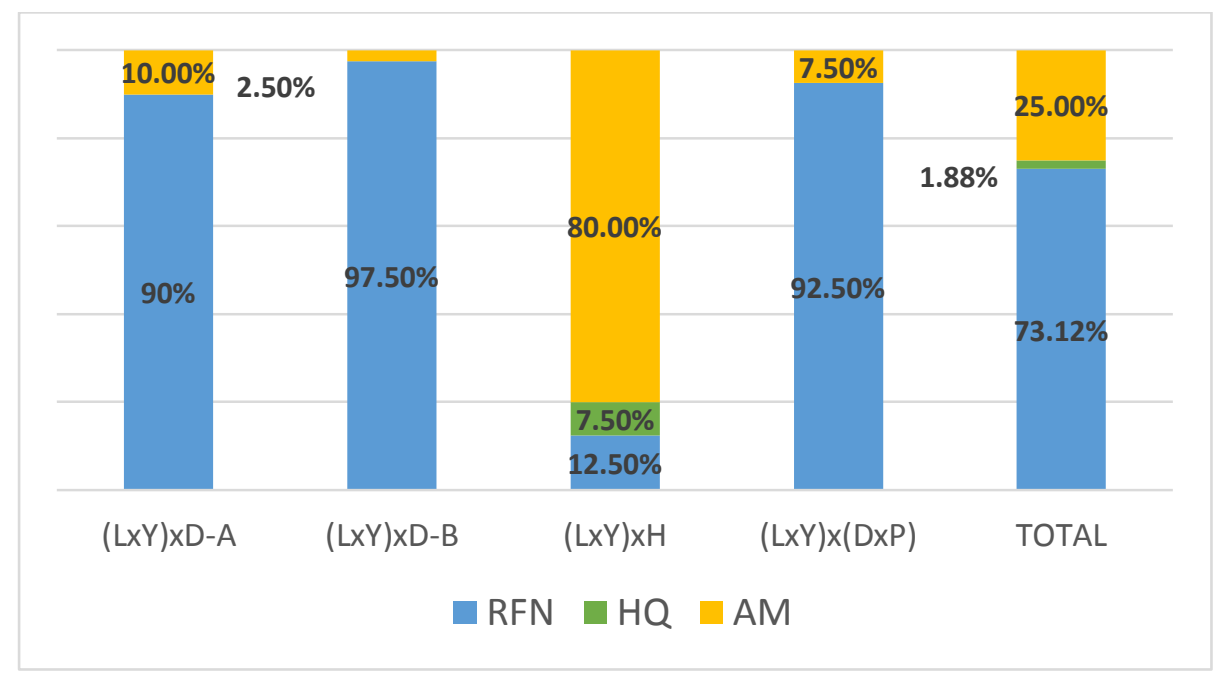

Figure 4 Frequencies (\%) of meat quality classes based on $\mathrm{EC}_{2}$ and $\mathrm{pH}_{48}$ parameters and genetic groups $(L \times Y) \times D-A-($ Landrace $\times$ Yorkshire $) \times$ Duroc-A (paternal component from Poland); $(L \times Y) \times D-B($ Landrace $\times$ Yorkshire $) \times$ Duroc-A (paternal component from Denmark); $(\mathrm{L} \times \mathrm{Y}) \times \mathrm{H}-($ Landrace $\times$ Yorkshire) $\times$ Hampshire; $(\mathrm{L} \times \mathrm{Y}) \times(\mathrm{D} \times \mathrm{P})-$ (Landrace $\times$ Yorkshire $) \times($ Duroc $\times$ Piétrain $)$

RFN - reddish-pink, firm and non-exudative; HQ - high quality; AM - acid meat

\section{Conclusion}

According to the low frequency of $A M$ in $(L \times Y) \times H$ fatteners obtained in Method I and Method II $p H$ measured 24 hours post mortem should not be regarded as ultimate $\mathrm{pH}\left(\mathrm{pH}_{\mathrm{u}}\right)$ in pork meat quality evaluation. Diagnostic methods exploiting the $\mathrm{pH}_{48}$ parameter, for example Method III and Method IV, presented notably higher values of $A M$ assessment in crossbreeds with Hampshire and Duroc. These changes should be taken into consideration by meat plants, because assessment of AM 48 hours after slaughter is too late for proper meat classification which should be carried out in the pre-rigor period. The solution might be the implementation of rapid diagnostic methods that are suitable for online usage such as vibrational spectroscopy. The most promising is Raman and Fourier infrared spectroscopy (Andersen et al., 2017). For example, according to Scheier et al. (2015) and Nache et al. (2016) Raman spectroscopy is fully applicable in the abattoir for $\mathrm{pH}$ monitoring.

\section{Authors' Contributions}

KT designed the study and analysed the data. HS revised the manuscript. AZ, EK-N and KA edited the layout and content of the manuscript. All authors approved the final manuscript after critical revision.

\section{Conflict of Interest Declaration}

The authors declare that there is no conflict of interest between them and other people or organizations that could inappropriately bias the results.

\section{References}

Alcalde, M.J., Ripoll, G. \& Panea, B., 2013. Consumer attitudes towards meat consumption in Spain with special reference to quality marks and kid meat. Consumer attitudes to food quality products. EAAP 133, 97-107.

Andersen, P.V., Veiseth-Kent, E. \& Wold, P.J., 2017. Analyzing pH-induced changes in a myofibril model system with vibrational and fluorescence spectroscopy. Meat Sci. 125, 1-9.

AOAC, 2000. Official Methods of Analysis. 17 edition. Association of Official Analytical Chemists (AOAC), Washington DC, USA.

Bergmeyer, H.U., 1974. Methods of Enzymatic Analysis. Academic Press, New York, USA.

Blixt, Y. \& Borch, E., 2002. Comparison of shelf life of vacuum-packed pork and beef. Meat Sci. 60, 371-378.

Breidenstein, B.C. \& Williams, J.C., 1987. Contribution of red meat to the US diet: National Live Stock and Meat Board, Chicago.

Dalrymple, R.H. \& Hamm, R., 1973. A method for the extraction of glycogen and metabolites from a single muscle sample. J. Food Technol. 8, 439-444. doi: 10.1111/j.1365-2621.1973.tb01730.x.

Deutscher Fleisch-Verband, 2003. Geschäfts. 2002/2003. October, Frankfurt, Germany. (in German)

Fischer, K., 2007. Drip loss in pork: Influencing factors and relation to further meat quality traits. J. Anim. Breed. Gen. 124, Suppl. 1, 12-18. 
Fujii, J., Otsu, K., Zorzato, F., de Leon, S., Khanna, V.K., Weiler, J.E., O’Brien, P.J. \& MacLennan, D.H., 1991. Identification of a mutation in porcine ryanodine receptor associated with malignant hyperthermia. Science 253, 448-450.

Grau, R. \& Hamm, R., 1952. Eine einfache Methode zur Bestimmung der Wasserbindung in Fleisch. Fleischwirt. 4, 295-297. (in German).

Honikel, K.O. \& Fischer, H., 1977. A rapid method for the detection of PSE and DFD porcine muscles. J. Food Sci. 42 , 1633-1636. doi: 10.1111/j.1365-2621.1977.tb08444.x.

Houde, A., Bard, L., Poitras, E., Gariepy, C., Chesnais, J., Milan, D. \& Gariepy, C., 2002. Determination of the frequency of the $\mathrm{RN}^{-}$gene in the breeds of pigs used for breeding purposes in Canada. AAFC publication, SIGPI Project \# 1787.

Huff-Lonergan, E. \& Lonergan, S.M., 2005. Mechanisms of water-holding capacity of meat: The role of post-mortem biochemical and structural changes. Meat Sci. 71, 194-204.

Kawasaki, E.S., 1990. Sample preparation from blood cells and other fluids. In: M.A. Innis, D.H. Gelfamd, J.J. Sninsky \& T.J. White (eds). PCR protocols: A guide to methods and applications. Academic Press, New York London, UK, pp. 146-152.

Koćwin-Podsiadła, M., Krzęcio, E. \& Przybylski, W., 2006. Pork quality and methods of its evaluation - a review. Pol. J. Food Nutr. Sci. 15/56, 3, 241-248.

Monin, G. \& Sellier P., 1985. Pork of low technological quality with a normal rate of muscle pH fall in the immediate postmortem period: The case of the Hampshire breed. Meat Sci. 13, 49-63.

Nache, M., Jörg, J., Scheier, R., Schmidt, H. \& Hitzmann, B., 2016. Prediction of the pH as indicator of porcine meat quality using Raman spectroscopy and metaheuristics. Chem. Intell. Lab. Sys. 154, 45-51.

Naveau, J., Pommeret, P. \& Lechaux, P., 1985. Proposition d'une méthode de mesuredu rendement technologique: la méthode Napole. Techni-Porc. 8, 7-13. (in French).

OECD-FAO Agricultural Outlook 2015-2014. http://www.fao.org/3/a-i4738e.pdf.

Otto, G., Knap, P.W., Roehe, R., Looft, H., Cavero, D. \& Kalm, E., 2007. Different approaches of estimating economical values for drip loss as log normally distributed trait. Livest. Sci. 112, 43-51.

Pohja, N.S. \& Ninivaara, F.P., 1957. Die Bestimmung der Wasserbindung des Fleisches mittels der Konsandrückmethods. Fleischwirt. 9, 193-195. (in German)

Prange, H., Jugrrt, L. \& Scharner, E., 1977. Untersuchungen zur Muskel fleischqualitätbeim Schwein. Arch. Exp. Vet. Med. Leipzig 31, 2, 235-248. (in German)

Przybylski, W., Jaworska, D., Boruszewska, K., Borejko, M. \& Podsiadły, W., 2012. Jakość technologiczna i sensoryczna wadliwego mięsa wieprzowego. Żywność. Nauka. Technologia. Jakość. 1, 80, 116-127. (in Polish, English abstract).

Schäfer, A., Rosenvold, K., Purslow, P., Andersen, H. \& Henckel, P., 2002. Physiological and structural events post mortem of importance for drip loss in pork. Meat Sci. 61, 355-366.

Scheier, R., Scheeder, M. \& Schmidt, H., 2015. Prediction of pork quality at the slaughter line using a portable Raman device. Meat Sci. 103, 96-103.

Sieczkowska, H., Koćwin-Podsiadła, M., Krzęcio, E., Antosik, K., Zybert, A. \& Włoszek, E., 2009. Mięsność i jakość mięsa mieszańców (Landrace $\times$ Yorkshire) $\times$ Duroc oraz (Landrace $\times$ Yorkshire) $\times$ Hampshire. Rocz. Nauk. Pol. Tow. Zoot. 5, 4, 209-218. (in Polish).

Sieczkowska, H., Koćwin-Podsiadła, M., Antosik, K., Krzęcio, E., Zybert, A. \& Korszeń, Ł., 2010. Charakterystyka jakości surowca wieprzowego wybranych grup rasowych tuczników. Rocz. Nauk. Pol. Tow. Zoot. 6, 4, 363-374. (in Polish).

Valsta, L.M., Tapanainen, H. \& Mannisto, S., 2005. Meat fats in nutrition. Meat Sci. 70, 525-530.

Verbeke, V., Frewer, L.J., Scholderer, J. \& de Brabander, H.F., 2007. Why consumers behave as they do with respect to food safety and risk information. Anal. Chim. Acta 586, 2-7.

Zybert, A., Krzęcio, E., Sieczkowska, H., Antosik, K., Podsiadły, W. \& Koćwin-Podsiadła, M., 2008. Relationship between glycolytic potential and some physico-chemical and functional traits of longissimus lumborum muscle including chilling method of carcasses. Rocz. Nauk. Pol. Tow. Zoot, 4, 301-309. 